\title{
Article \\ Modification of TiAlV Alloys with Hybrid Layers Containing Metallic Nanoparticles Obtained by the Sol-Gel Method: Surface and Structural Properties
}

\author{
Magdalena Ziąbka ${ }^{1, *(D)}$, Katarzyna Matysiak ${ }^{1}$, Katarzyna Walczak ${ }^{2}$, Marcin Gajek ${ }^{1}$ (D) \\ and Katarzyna Cholewa-Kowalska ${ }^{3}$ (D)
}

1 Department of Ceramics and Refractories, Faculty of Materials Science and Ceramics, AGH University of Science and Technology, 30-059 Krakow, Poland; katarzyna.matysiak@poczta.onet.pl (K.M.); mgajek@agh.edu.pl (M.G.)

2 Department of Hydrogen Energy, Faculty of Energy and Fuels, AGH University of Science and Technology, 30-059 Krakow, Poland; walczakk@agh.edu.pl

3 Department of Glass Technology and Amorphous Coatings, Faculty of Materials Science and Ceramics, AGH University of Science and Technology, 30-059 Krakow, Poland; cholewa@agh.edu.pl

* Correspondence: ziabka@agh.edu.pl; Tel.: +48-012-617-2523

check for

updates

Citation: Ziąbka, M.; Matysiak, K.;

Walczak, K.; Gajek, M.;

Cholewa-Kowalska, K. Modification of TiAlV Alloys with Hybrid Layers Containing Metallic Nanoparticles Obtained by the Sol-Gel Method: Surface and Structural Properties. Int J. Mol. Sci. 2022, 23, 2283. https:// doi.org/10.3390/ijms23042283

Academic Editor: Andrea Salis

Received: 8 January 2022

Accepted: 17 February 2022

Published: 18 February 2022

Publisher's Note: MDPI stays neutral with regard to jurisdictional claims in published maps and institutional affiliations.

Copyright: (c) 2022 by the authors. Licensee MDPI, Basel, Switzerland. This article is an open access article distributed under the terms and conditions of the Creative Commons Attribution (CC BY) license (https:// creativecommons.org/licenses/by/ $4.0 /)$.

\begin{abstract}
The aim of the work was to obtain hybrid coatings containing silver, copper, and zinc nanoparticles on the TiAlV medical alloy via a sol-gel process. The developed layers were designed to bring about a bactericidal and fungicidal effect, as well as for protection against surgical scratches during the implantation of implants used in veterinary medicine. In this work, the authors focused on evaluating the microstructure (SEM + EDS); the structure (XRD, FTIR); and the surface properties, such as wettability, free surface energy, and roughness of layers with various concentrations of metallic nanoparticles ( 2 and $5 \mathrm{~mol} \%$ ). Our results confirmed that the sol-gel method enables the easy manufacturing of hybrid layers endowed with different porosity values as well as various shapes and sizes of metallic nanoparticles. A higher concentration of nanoparticles was observed on the surface containing $5 \mathrm{~mol} \%$ of metallic salts. The highest degree of homogeneity was obtained for the layers containing silver nanoparticles. In addition, the silver nanoparticles were round and had the smallest dimensions, even below $20 \mathrm{~nm}$. The FTIR and XRD structural studies confirmed the presence of an organosilicon matrix containing all three types of the metallic particles. We conclude that the higher concentration of nanoparticles influenced the alloy surface parameters.
\end{abstract}

Keywords: TiAlV alloy; silver; copper; zinc nanoparticles; composite hybrid layers; sol-gel; structural and surface properties

\section{Introduction}

Titanium and its alloys have been widely used in medicine for many years. Their applicability is based on the advantageous physical and chemical properties and good biocompatibility with human cells and tissues. Light, strong, and completely biocompatible titanium is one of the few materials that naturally meet the requirements of implantation in the human body. Titanium alloys have a much higher strength/mass ratio in comparison to stainless steel, their main competitor on the medical market.

The most frequently used titanium alloys are the ones with aluminum and vanadium (Ti6Al4V); with aluminum and niobium (Ti6Al7Nb); with aluminum and iron (Ti5Al2.5Fe); with niobium and zirconium (Ti13Nb13Zr); and with molybdenum, zirconium, and iron (Ti12Mo6Zr2Fe) [1-4]. Titanium and its alloys are most commonly used for orthopedic implants, such as hip joint prosthesis [5], knee implants [6], implants for external or internal stabilization of bone fractures [7], tiles, bolts, nails for osteosynthesis, spine stiffening devices [8], pins, bone tiles, bolts, intramedullary nails and external stabilizers [9,10], 
carbonized frames, and dental implants [11]. Titanium is also regularly used in the case of heart pacemakers and defibrillators, as a carrier structure for replacing the heart valve, and for intravascular stents [12]. Titanium is also used to develop external devices, as well as for orthotic terminals, artificial limbs, and surgical tools.

The Ti6Al4V alloy has optimal mechanical properties, very good corrosion resistance, and a two-phase structure $\alpha+\beta$. The alloy is obtained by introducing an aluminum additive that reduces the specific gravity of titanium and strengthens a solid solution. Then, vanadium is introduced as a stabilizing element of the $\beta$ phase [13]. However, the release of vanadium to the physiological environment is problematic, as it causes cytotoxic reactions and consequently neurogenic and carcinogenic disorders [14,15].

There are several approaches to reduce the penetration of ions in the environment and thus to increase the corrosion resistance and improve the tribological properties of titanium alloys. Firstly, the alloy elements may be carefully selected. Secondly, the alloys may be covered with protective layers. Thirdly, several techniques of surface processing may be applied. With regard to the layer formation mechanism, the modification techniques consist among others chemical and physical processes. Chemical methods include: chemical treatment, electrochemical treatment (anodic oxidation), sol-gel, chemical vapor deposition (CVD), and biochemical modification. In the case of physical methods, the formation of the surface layer on titanium alloys is mainly attributed to the thermal, kinetic, and electrical energy. These techniques comprise thermal spraying, physical vapor deposition (PVD), glow discharge plasma, and ion implantation [16-18].

The mentioned above, sol-gel is a chemical method used to synthesize ceramic or glass materials in a relatively low temperature [19] through hydrolysis and condensation of metal alkoxide precursors. One of its advantages is the low heating temperature that does not result in thermal stresses in the material. This method is therefore used to obtain bioactive layers (e.g., hydroxyapatite, bioglass) that protect the metallic implant surface, improving the implant-bone integration via better adhesion and cell proliferation [20]. In addition, this technique is low-cost, and it allows for the coating of elements of geometrically complex shapes [21]. On the other hand, the sol-gel method results in a fragile inorganic component that can be eliminated by introducing organically modified precursors. This method allows for the creation of flexible hybrid organic-inorganic materials with the possibility of tailoring and modifying their composition, structure, and thickness to the desired application [22,23].

An important problem appearing when using medical implants is a bacterial infection leading to chronic infections and prolonged antibiotic therapy. In some cases, it is even necessary to remove the implant, triggering another operation and additional stress and pain for a patient, leading to longer hospitalization. It is also connected with higher costs of treatment and rehabilitation. In many cases, an issue is the bacterial resistance to an antibiotic therapy. In the sol-gel method, the bactericidal effect can be ensured, inter alia, by introducing antibacterial agents such as silver, copper, and zinc [24]. The sol-gel technique offers a unique opportunity to incorporate antibacterial components into a pure organically modified silica matrix. By dissolving $\mathrm{Ag} / \mathrm{Cu} / \mathrm{Zn}$ nitrates in the silica sol, one can obtain a metal-doped coating on various surfaces by the simple coating technique, such as dipping, spraying, or spinning [25-28]. When designing hybrid layers with biocidal properties, one should also remember that the process of developing materials itself is extremely important. Both the precursors and the synthesis conditions have to be precisely selected in order to ensure adequate physicochemical and biological properties. These factors are crucial in order to obtain homogeneous and resistant layers that meet the mechanical and biological requirements, such as biocompatibility and bactericidal activity [29].

The presented study describes an attempt to develop the homogeneous organicinorganic layers containing nanoparticles of biocidal metals (silver, copper, zinc) on the substrate of the Ti6Al4V alloy. The sol-gel technique was used to protect the modified substrates against corrosion and scratching protection and to ensure antibacterial action while maintaining the biocompatibility of materials. This article is the first part of the 
research investigating the characteristics of the microstructural and surface properties of the obtained layers. In the next work, we will describe the bactericidal properties and confirm the biocompatibility of the developed layers.

In this work, scanning electron microscopy (SEM), X-ray diffractometry (XRD), Fourier transform infrared (FTIR) spectroscopy, profilometry, wettability, and confocal microscopy were employed to analyze the surface chemical compositions, microstructure, phases, and surface properties.

\section{Results and Discussion}

The organic-inorganic sol-gel materials with increasing amounts of $\mathrm{Ag} / \mathrm{Cu} / \mathrm{Zn}$ were successfully synthesized and applied as coatings onto the TiAl4V discs. As anticipated, NPs formed as a result of chemical reactions in sols, and subsequent thermal treatment of coating was observed in the layers. The SEM surface observations confirmed the presence of metallic nanoparticles on the surface of the TiAlV alloy. In the case of layers containing silver nanoparticles, a homogeneous distribution of spherical nanoparticles was revealed over the entire observed surface (Figure 1a,b). The silver particles size was estimated on the basis of 10 measurements made with the automatic function of measuring the particle diameter with a microscope ruler. The AgNP particle diameter was 5-20 nm for the layers containing both 2 and $5 \mathrm{~mol} \%$ of the silver nitrate precursor. The average EDS chemical analysis performed in the area of $285 \times 285 \mu \mathrm{m}$ confirmed the presence of silver in the layers. The silver content constituted about $1 \%$ by weight for the layers with $2 \mathrm{~mol} \%$ of the precursor. Observations of the silver-doped layers at a magnification of $10,000 \times$ showed that the layers were homogeneous, and no porosity or presence of agglomerates was observed (Figure 1c,f). In the case of layers containing $5 \mathrm{~mol} \%$ of the precursor, a higher proportion of silver nanoparticles was observed (Figure 1e). This was also confirmed by the EDS analysis, which showed the $2 \%$ weight of AgNPs for the layers with $5 \mathrm{~mol} \%$ of the precursor.

The surface observations of the layers containing copper nanoparticles revealed the presence of particles measuring 100-500 $\mathrm{nm}$ in diameter (Figure 2a,b,d,e). The particles were not distributed homogeneously-there were areas with no particles at all, as well as areas with spherical agglomerates of $500 \mathrm{~nm}$ (Figure 2e). The particles with the appearance of flocculent clouds dominated on the layers surface. In the case of layers containing $2 \mathrm{~mol}$ $\%$ of copper nitrate precursor, the layer appeared to be smooth and uniform, with no signs of microcracking or porosity (Figure 2c). On the other hand, for the layers containing $5 \mathrm{~mol}$ $\%$ of copper precursor, both an increase in the content of copper particles and an increase in their diameter was observed. The areas with high concentration of nanoparticles were visible at the magnification of $10,000 \times$ (Figure $2 \mathrm{f}$ ). The average EDS analysis performed in the area of the layers $285 \times 285 \mu \mathrm{m}$ revealed a copper concentration of $0.5 \mathrm{wt} \%$ for the $\mathrm{TiAlV} / \mathrm{h} 2 \mathrm{Cu}$ layer and $1.6 \mathrm{wt} \%$ for the TiAlV $/ \mathrm{h} 5 \mathrm{Cu}$ layer.

The microstructural observations of the zinc-doped layers revealed the presence of zinc nanoparticles measuring $20-85 \mathrm{~nm}$ in diameters for the layers with $2 \mathrm{~mol} \%$ zinc nitrate precursor (Figure $3 \mathrm{a}, \mathrm{b}$ ) and $60-140 \mathrm{~nm}$ for the layers with $5 \mathrm{~mol} \%$ precursor. There were also the areas with local concentration of zinc nanoparticles observed. At 10,000× magnification (Figure 3c), no porosity was noticed, and the surface of the layer was smooth. On the other hand, for the TiAlV/h5Zn layers, the network porosity with round pores appeared, with a pore size of about 700-900 $\mathrm{nm}$ (Figure 3d-f). The average EDS analysis performed for the areas analogous to the silver and copper layers confirmed the chemical presence of zinc of $0.8 \%$ by weight for the TiAlV $/ \mathrm{h} 2 \mathrm{Zn}$ layer and $5.3 \%$ by weight for the TiAlV/h5Zn layer. The ZnNPs nanoparticles were present both in the pores and on the network surface. 

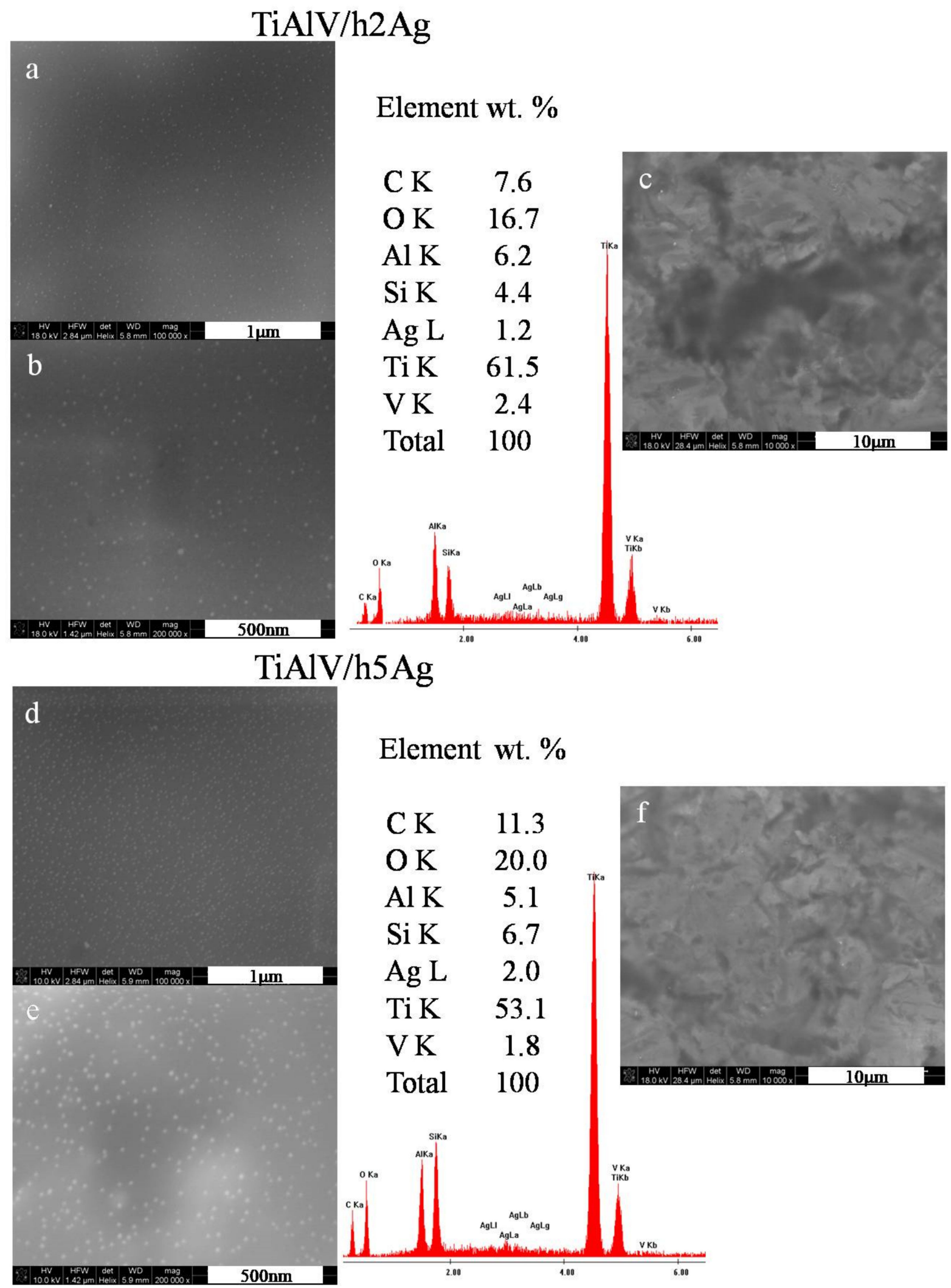

Figure 1. SEM images and EDS spectra of titanium alloy (TiAlV)-covered sol-gel hybrid layer containing silver nanoparticles; (a-c) containing $2 \%$ AgNPs, and (d-f) containing $5 \%$ AgNPs. 


\section{$\mathrm{TiAlV} / \mathrm{h} 2 \mathrm{Cu}$}
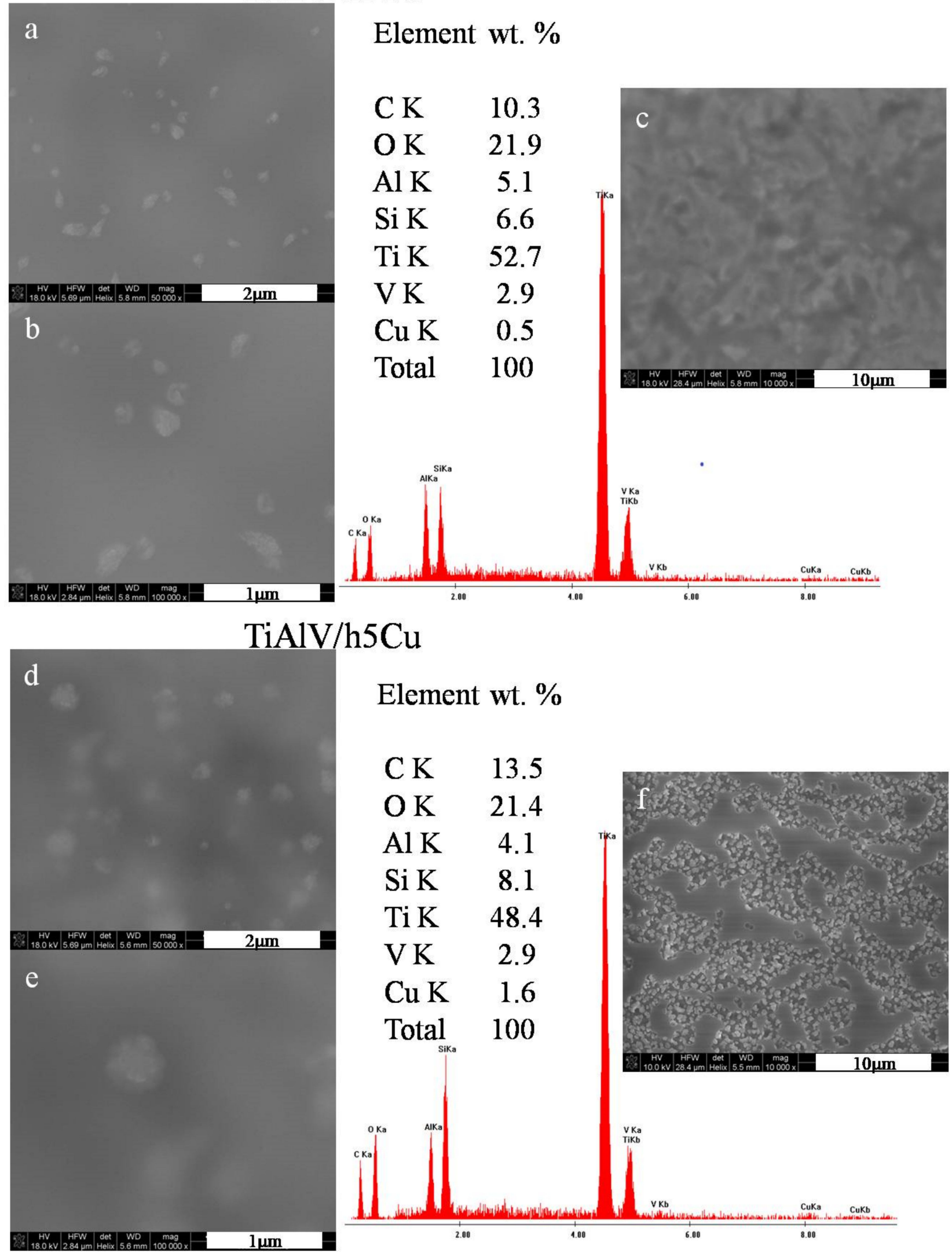

Element wt. \%

C K $\quad 13.5$

O K 21.4

$\mathrm{Al} \mathrm{K} \quad 4.1$

Si K $\quad 8.1$
TiK

TiK $\quad 48.4$

VK 2.9

$\mathrm{Cu} \mathrm{K} \quad 1.6$

Total 100

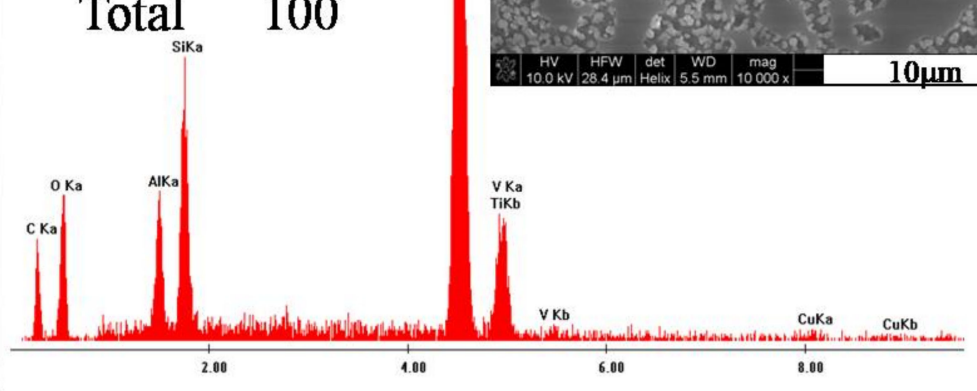

Figure 2. SEM images and EDS spectra of titanium alloy (TiAlV)-covered sol-gel hybrid layer containing copper nanoparticles; $(\mathbf{a}-\mathbf{c})$ containing $2 \%$ CuNPs, and $(\mathbf{d}-\mathbf{f})$ containing $5 \%$ CuNPs. 


\section{TiAlV/h2Zn}
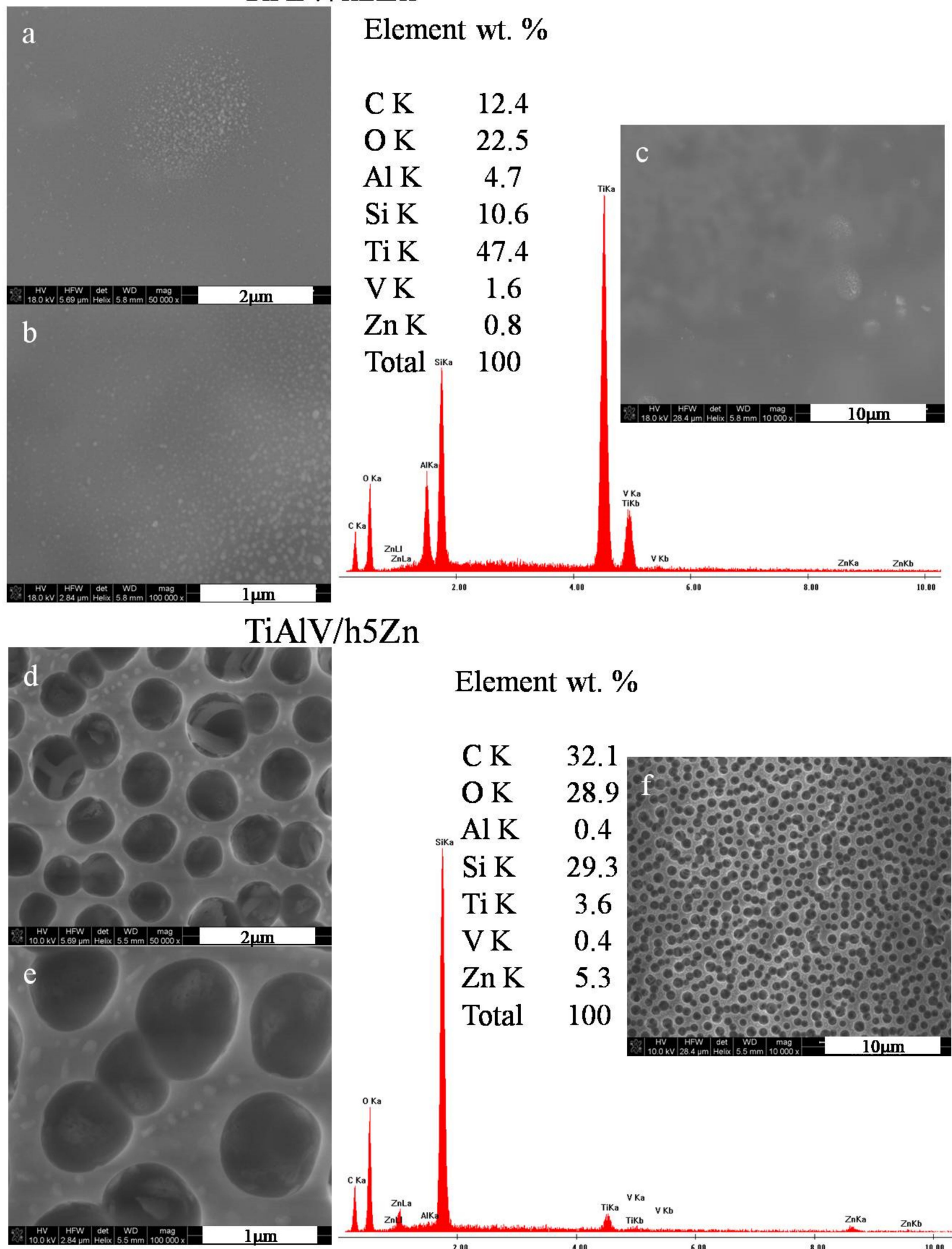

Element wt. \%

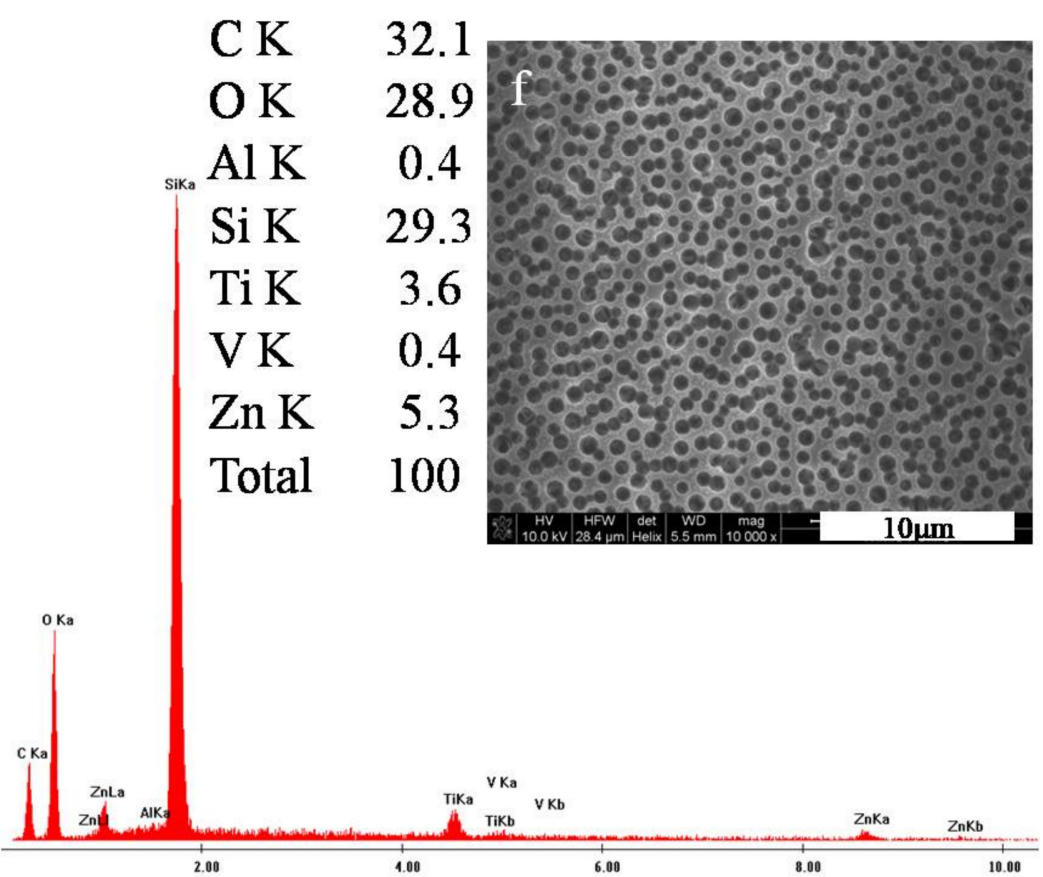

Figure 3. SEM images and EDS spectra of titanium alloy (TiAlV)-covered sol-gel hybrid layer containing zinc nanoparticles; (a-c) containing $2 \%$ ZnNPs, and (d-f) containing $5 \%$ ZnNPs. 
The films, prepared with $\mathrm{AgNO}_{3}$, regardless of the concentration, exhibited AgNPs 5-20 $\mathrm{nm}$ in diameter, and only the number of Ag clusters increased with the increasing $\mathrm{AgNO}_{3}$ content. In the case of the $\mathrm{Cu}$ - and $\mathrm{Zn}$-doped coatings, the nanoparticle size and number increased with the increasing initial components concentration. The formation of the $\mathrm{Ag} / \mathrm{Cu} / \mathrm{Zn}$ particles suggested that a reduction of the ionic form to colloidal metal had occurred. It was reported that the functional groups (amine, thiocyanate) as well as the organically modified silanes acted as a complexing and reducing agent for metal ions in sol-gel-derived $\mathrm{SiO}_{2}$ coatings. In this study, we also expected that the organic groups of the used organically modified silane (TMSPM) would act as a redactor and lead to the metal colloid formation during the proposed thermal treatment in air [30-33].

In order to confirm that the base sample contained TiAlV alloy, we employed the XRD measurements. The diffractogram in Figure $4 \mathrm{a}$ indicated the presence of high peaks, originating from hexagonal $\left(P 6_{3} / m m c\right)$ and trigonal $(P \overline{3} m 1)$ space groups, which were ascribed to metallic alloys $\mathrm{TiV}$ and $\mathrm{TiAlV}$, respectively. These results stayed in line with our previous studies [34]. Figure $4 \mathrm{~b}$ shows the diffractogram of the base sample with the antibacterial layer consisting of the $\mathrm{SiO}_{2}$ matrix with silver nanoparticles (5\%). Since the peaks from $\mathrm{TiV}$ and $\mathrm{TiAlV}$ were of high intensity, it was only possible to see small reflections coming from silver, especially at around $32.2^{\circ}, 37.1^{\circ}$, and $43.4^{\circ}$.

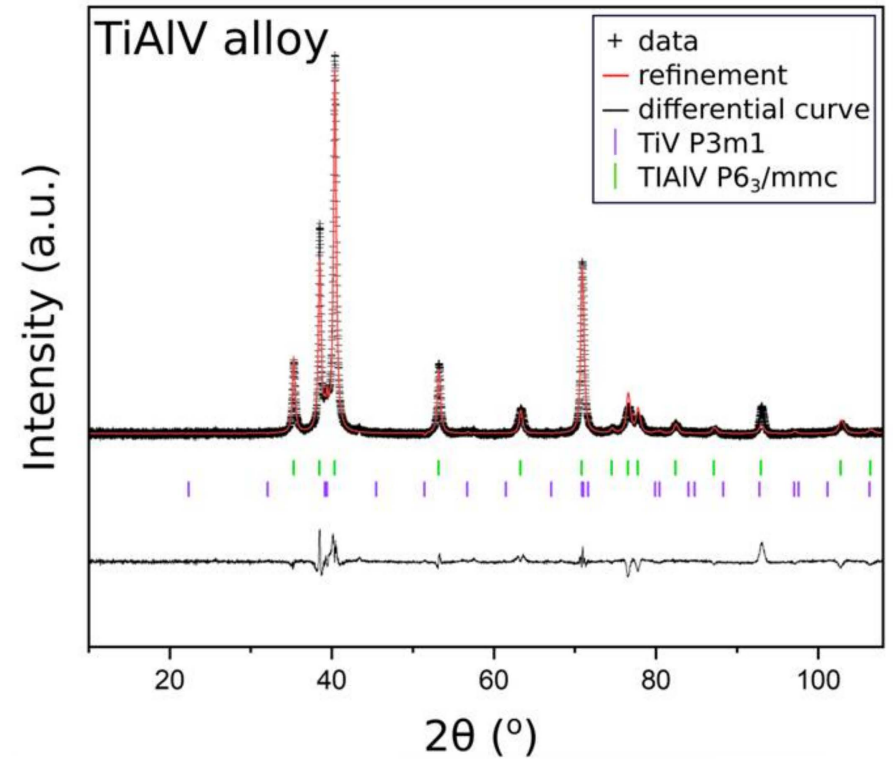

(a)

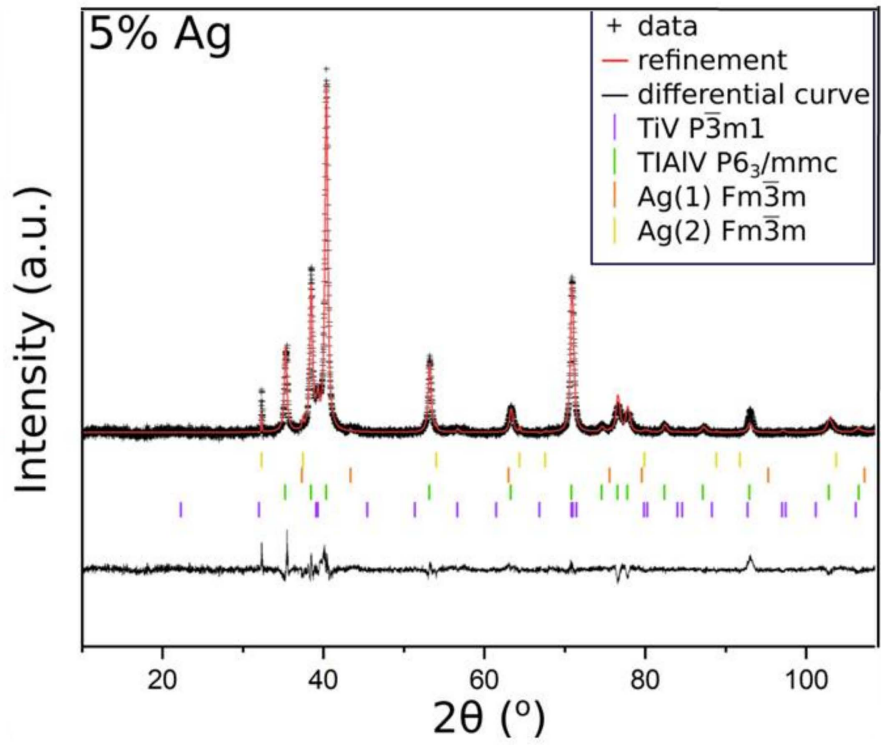

(b)

Figure 4. XRD patterns of the TiAlV alloy (a); the TiAlV alloy with 5\% silver nanoparticles in the $\mathrm{SiO}_{2}$ matrix (b).

It must be noted that for a smaller content of metallic nanoparticles, similar observations were not possible. Thus, in order to confirm the presence of metallic nanoparticles in other samples, we needed to conduct the measurements at the glassy (amorphous) base (Figure 5). For all samples, the broad hump (at 20: 25-35 $)$ typical for the amorphous phase was observed. Moreover, the diffractogram of the glass base revealed the presence of a small peak, near $29^{\circ} 2 \theta$ angle, assigned to crystalline $\mathrm{SiO}_{2}$ [35]. The XRD patterns of the samples with silver, copper, and zinc nanoparticles showed that the main peak overlapped with the $\mathrm{SiO}_{2}$ reflection. What is more, this reflection increased with the increase in the metallic nanoparticles content in the matrix. Nevertheless, despite the glassy base, the visible reflections were small and low-intensity-a result of the grain nanosize (see the SEM analysis). 

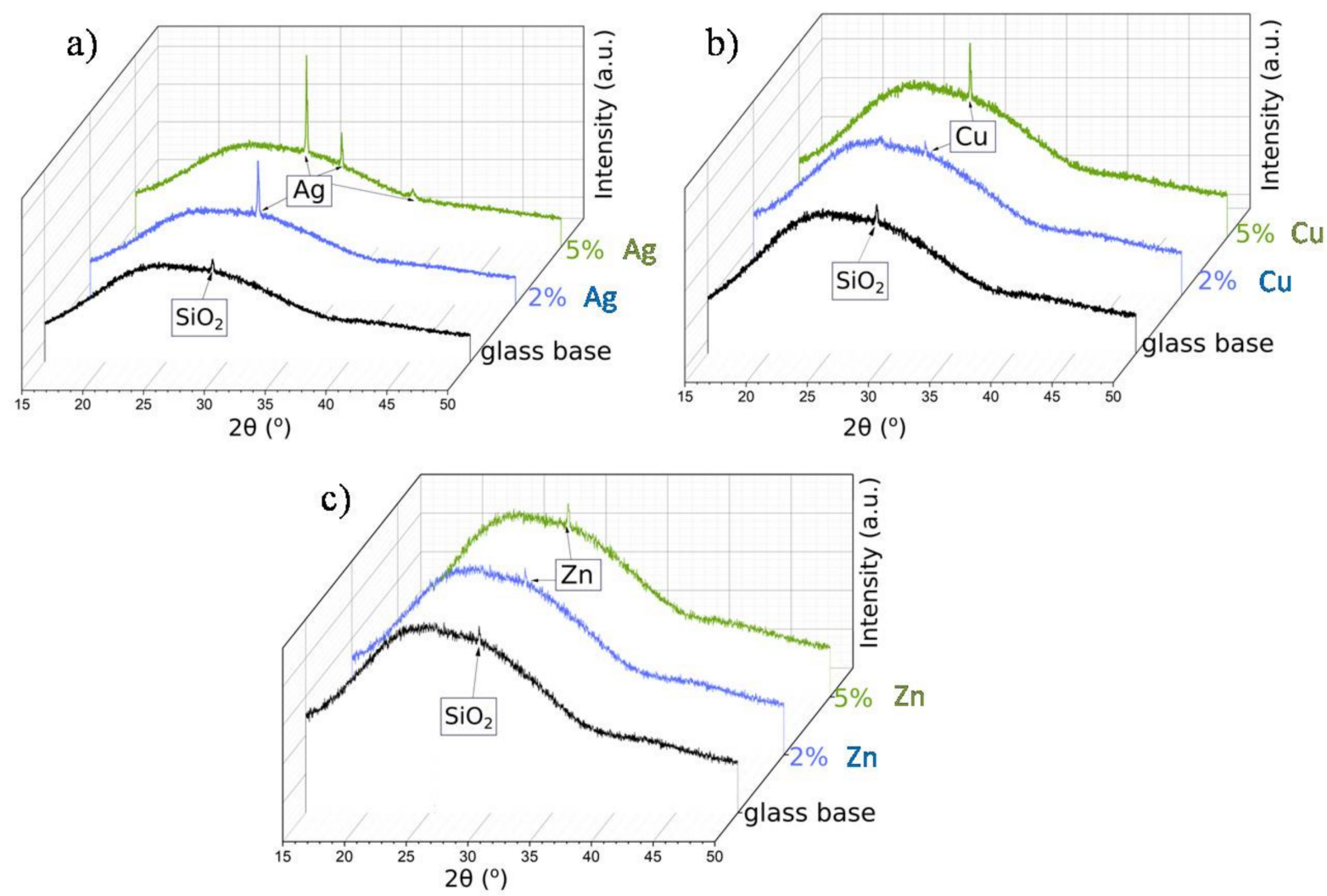

Figure 5. XRD patterns of the metallic nanoparticles in $\mathrm{SiO}_{2}$ matrix on the glassy base: $\mathrm{Ag}(\mathbf{a}), \mathrm{Cu}(\mathbf{b})$, and $\mathrm{Zn}(\mathrm{c})$ at various percentage contents.

Figure 6 shows the FTIR spectra of the coatings in the $400-4000 \mathrm{~cm}^{-1}$ region. In all the spectra, the wide band located in the $3100-3600 \mathrm{~cm}^{-1}$ spectral region was assigned to the contribution of physically and/or chemically incorporated water, corresponding to the $\mathrm{OH}$ symmetric stretching from asymmetrically hydrogen bonded water. The $\mathrm{CH}$ alkyl stretching bands were observed in the $2890-2960 \mathrm{~cm}^{-1}$ region [36,37]. The peaks at 1636 and $1716 \mathrm{~cm}^{-1}$ were characteristic for the $\mathrm{C}=\mathrm{C}$ and $\mathrm{C}=\mathrm{O}$ vibrations in the methacrylate group of TMSPM, respectively. Additionally, the vibrations bands at about 1454-1460, 1380 , and $1290 \mathrm{~cm}^{-1}$ were assigned to the $\mathrm{C}-\mathrm{H}$ bending vibration, the $\mathrm{C}-\mathrm{O}-\mathrm{C}$ skeletal vibrations, and the $\mathrm{C}-\mathrm{C}$ stretching vibrations, respectively [38,39]. It is likely that the band at $1380 \mathrm{~cm}^{-1}$ also covered the $\mathrm{CH}_{3}$ rocking vibrations. The $\mathrm{Si}-\mathrm{O}-\mathrm{Si}$ structure formation was supported by the presence of the strong asymmetric Si-O-Si stretching absorption at about $1020 \mathrm{~cm}^{-1}$, while the peak at $920 \mathrm{~cm}^{-1}$ reflected the contribution of the Si-O-Ti bond in the material structure, confirming the reaction of TIP with silane compounds, which leads to the cross-linked structure with incorporated Ti atoms [40,41]. The presence of additional peaks of the Si-containing groups at 770 and $490 \mathrm{~cm}^{-1}$, which were, respectively, assigned to the symmetric stretching and bending vibration modes of Si-O-Si bonds, also indicated the spatial silica-based structure formation.

In addition, the slight shift of the carbonyl absorption band to the frequency lower than $1720 \mathrm{~cm}^{-1}$, characteristic of carbonyl groups, revealed the formation of hydrogen bonds with the silane (TEOS) hydroxyl groups as well as the fact that the interaction between the carbonyl groups and metal nanoparticles probably occurred mainly through a physical force.

The FTIR data revealing the presence of bands associated with organic groups and the appearance of $\mathrm{Si}-\mathrm{O}-\mathrm{Si}$ and $\mathrm{Si}-\mathrm{O}-\mathrm{Ti}$ vibrations confirmed the copolymerisation of respective compounds, resulting in the formation of a homogeneous organic-inorganic hybrid layer. 


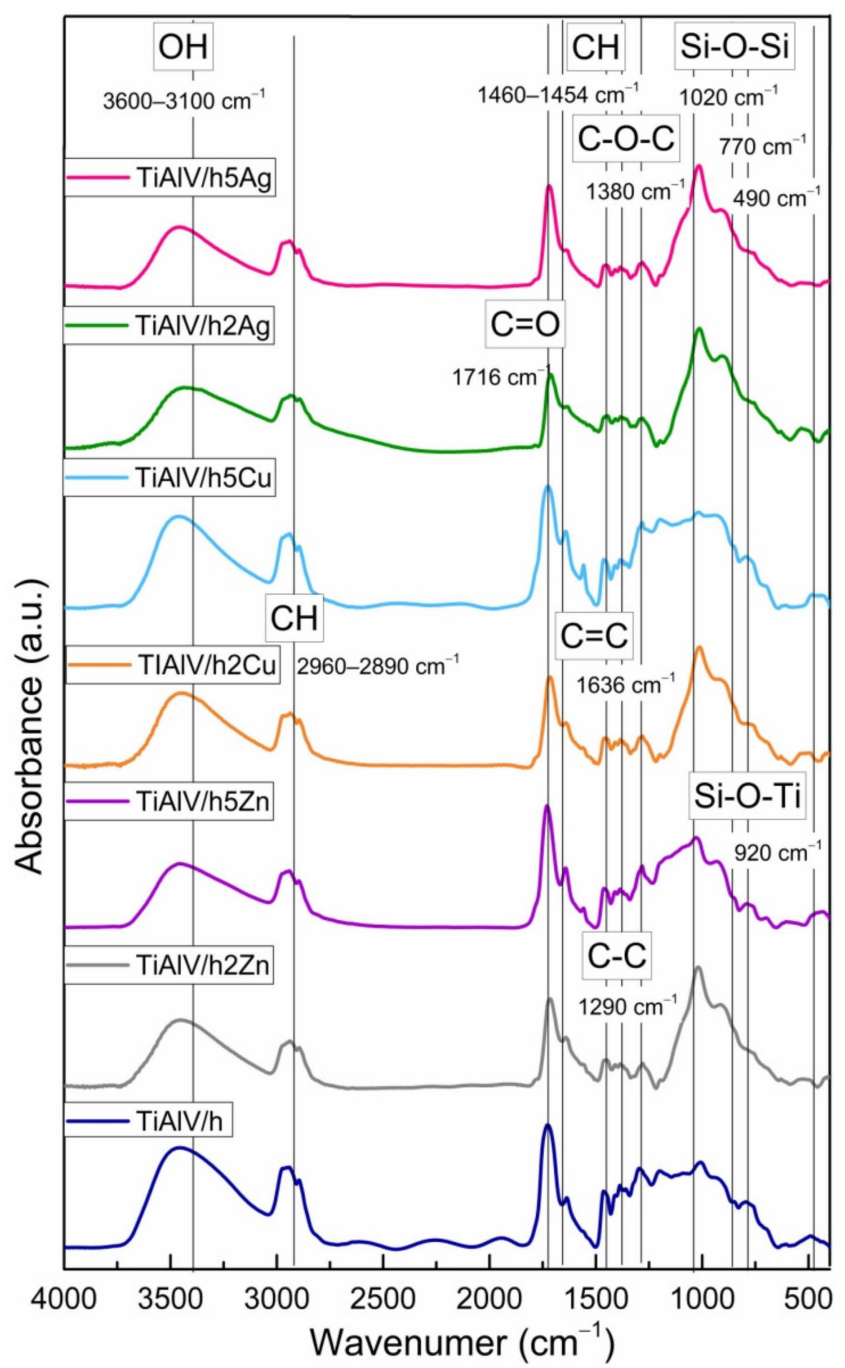

Figure 6. FTIR spectra of titanium alloy (TiAlV)-covered sol-gel hybrid layer containing 2 and $5 \mathrm{~mol} \%$ silver, copper, and zinc nanoparticles.

The TiAlV alloy modification with organic-inorganic layers had a significant impact on their surface properties. Covering the alloy with the base layer (TiAlV $/ \mathrm{h}$ ) resulted in an average increase in the contact angle by $0.5^{\circ}$ and a decrease in the surface energy by $0.2 \mathrm{mN} / \mathrm{m}$ (Figure $7 \mathrm{a}, \mathrm{b}$ ). In the case of the silver-doped layers, an increase in the value of the contact angle was observed, along with a higher nanoparticle content. For the $2 \%$ AgNPs layers, the contact angle increased by an average of $6^{\circ}$, and for the $5 \%$ AgNPs, the value increased by an average of $17^{\circ}$. Thus, a clear change from hydrophilic to hydrophobic nature was observed in the layers, which correlated with the surface energy change. The highest AgNPs caused an energy decrease by an average of $14.6 \mathrm{mN} / \mathrm{m}$, as compared to the pure alloy.

In the case of copper and zinc layers, a significant decrease in the contact angle and an increase in the surface energy were observed. The values of both parameters correlated with the content of metal nanoparticles. The smaller the proportion of metallic nanoparticles, the lower the contact angle and the higher the surface energy. For the $2 \%$ CuNP layers, the reduction of the contact angle was on average equal to $9^{\circ}$, and the energy increase was on average $0.3 \mathrm{mN} / \mathrm{m}$. For the $5 \%$ CuNPs layers, the contact angle decrease was $4^{\circ}$ on average, and the average energy increase was $1.3 \mathrm{mN} / \mathrm{m}$. As for the surface energy, for the $2 \%$ ZnNPs layers, the decrease in the contact angle was on average $3.8^{\circ}$, and there were no changes in the surface energy value. For the layers containing $5 \%$ 
$\mathrm{ZnNPs}$, the contact angle decreased by $1.5^{\circ}$ on average, and the energy value increased by $1.4 \mathrm{mN} / \mathrm{m}$ on average.

a)

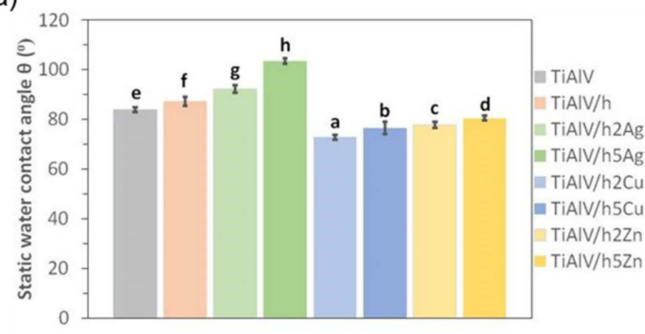

c)

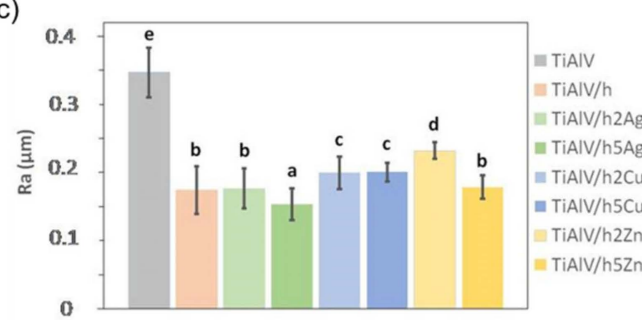

b)

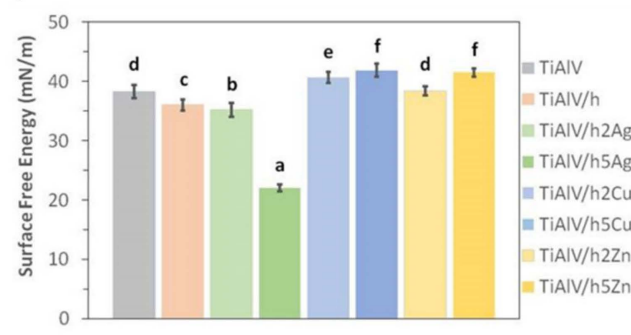

d)

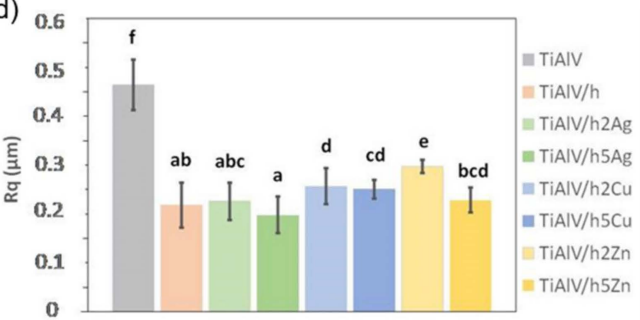

Figure 7. Static water contact angle (a), surface free energy (b), and roughness parameters (c,d) of titanium alloy (TiAlV)-covered sol-gel hybrid layer containing silver, copper, and zinc nanoparticles. Statistically significant differences $(p<0.05)$ in the studied parameters between the different coating types are indicated by different lower-case letters. Bars marked with the same letters are not statistically different.

When analyzing the surface roughness, we observed that the modification of the TiAlV alloy with the sol-gel layers significantly improved the samples' surface smoothness. The decrease in the $\mathrm{Ra}$ and $\mathrm{Rq}$ parameters was observed for all the tested layers in relation to the base alloy. In the case of the pure hybrid layer, the Ra parameter decreased by $0.10 \mu \mathrm{m}$ on average, and the Rq parameter by $0.15 \mu \mathrm{m}$. The introduction of metallic particles into the layers also reduced roughness parameters in comparison to pure alloy. Yet, only in the case of the $5 \mathrm{~mol} \% \mathrm{Ag}$ layers was the even lower Ra parameter value (reduction by $0.04 \mu \mathrm{m}$ ) recorded, as compared to the base layer. The addition of copper and zinc nanoparticles increased the Ra parameter, as compared to the base layer. Similar behavior was observed for the Rq parameter. The increase in the roughness of the layers containing copper and zinc nanoparticles related to the size of the particles formed in the layer their uneven distribution and the apparent porosity. Thus, the highest surface smoothness was obtained for the layers containing silver nanoparticles, which correlated with the SEM observations.

The surface roughness examinations performed with a confocal microscope (Figure 8) confirmed the convergence with the results obtained from the profilometer. The analogous values of the Sa parameter were observed for all the tested samples. The modification of the TiAlV alloy surface with the hybrid layers increased the surface smoothness. A significant decrease in the Sa parameter was observed for all the layers, while the highest surface smoothness was obtained for the 5\% AgNPs layer, with the Sa parameter $0.373 \mu \mathrm{m}$ lower than the pure alloy. The attempts to estimate the wetting angle of the coatings containing AgNPs, CuNPs, and ZnNPs showed that the influence of the surface topography was predominant. Such a significant increase in the contact angle for the $5 \mathrm{Ag}$ layer took place most likely due to the high concentration and the uniform distribution of nanoparticles. It was reported that the WCA (water contact angle) increased with the silica nanoparticle concentration increase; however, in that study, the contact angle increase may have been attributed to the surface roughness increase, contrary to our results [42]. As for the films with CuNPs and ZnNPs, it was most probably the case that the creation of porosity (SEM observation) made the samples more hydrophilic than the Ag-doped layers, due to the capillary lift of liquids through this network of pores $[43,44]$. 
TIAIV

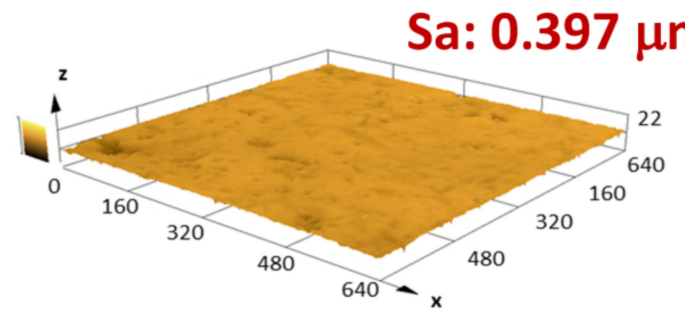

TIAIV/h2Ag

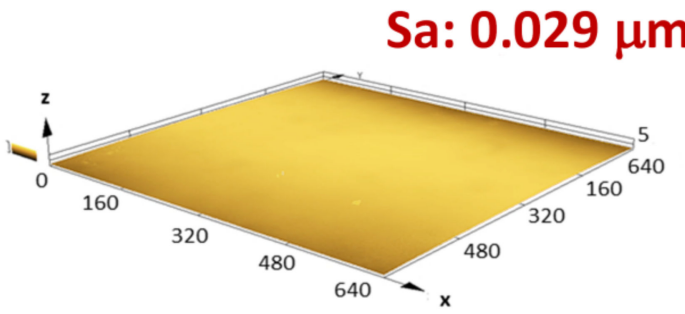

TIAIV/h2Cu

Sa: $0.042 \mu \mathrm{m}$
TIAIV/h

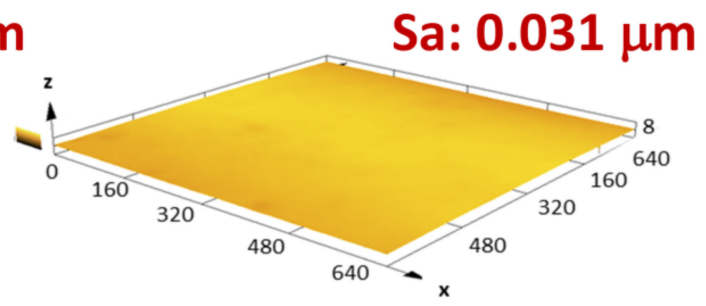

TIAIV/h5Ag

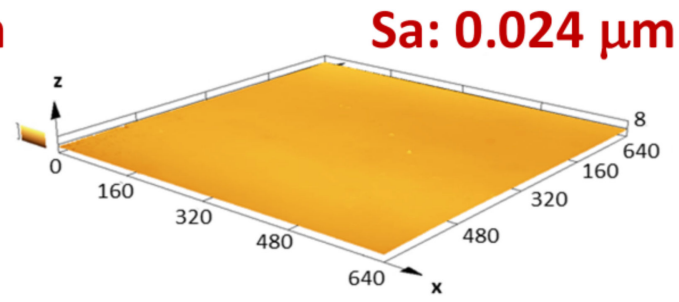

TIAIV/h5Cu

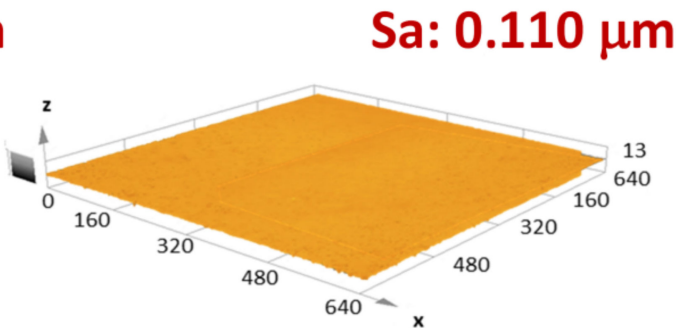

TIAIV/h5Zn

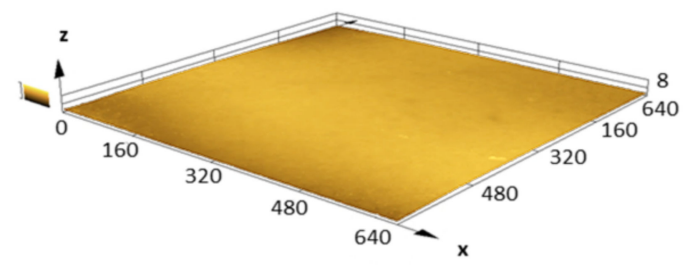

TIAIV/h2Zn

Sa: $0.068 \mu \mathrm{m}$

Sa: $0.082 \mu \mathrm{m}$

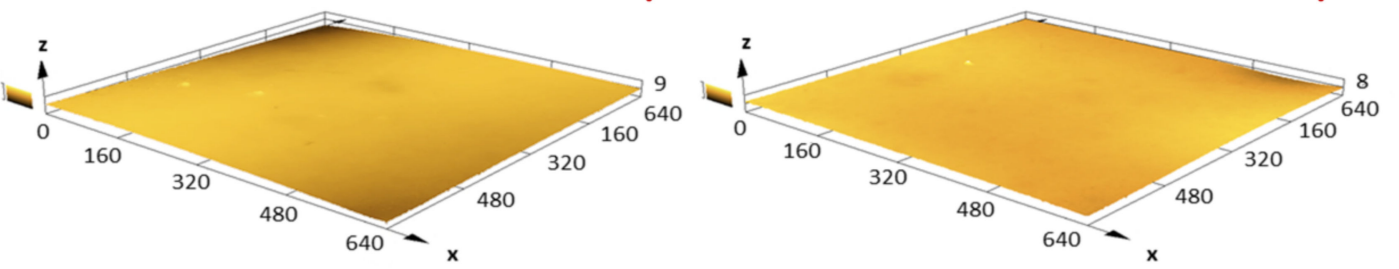

Figure 8. Three-dimensional confocal microscope microphotographs with area roughness parameter (Sa) of titanium alloy (TiAlV)-covered sol-gel hybrid layer containing silver, copper, and zinc nanoparticles. The scale in the charts is described in $\mu \mathrm{m}$.

\section{Materials and Methods}

\subsection{Material Manufacturing}

Metallic substrates (disks with a diameter of $1 \mathrm{~cm}$ ) made of the TiAlV alloy were manufactured and delivered by Medgal (Księżno, Poland). Composite hybrid (organic-inorganic silicate) sols for coating their surface were prepared by the sol-gel method. The chemical compositions of layers were designed with 2 and $5 \mathrm{~mol} \%$ concentrations of metallic precursors, respectively. The coating solution was prepared using the following precursors: TEOS (tetrethylorthosilicate, $\left.\mathrm{Si}\left(\mathrm{OC}_{2} \mathrm{H}_{5}\right)_{4}\right)$; TMSPM (3-(Trimethoxysilyl) propyl methacrylate, $\left.\mathrm{H}_{2} \mathrm{C}=\mathrm{C}\left(\mathrm{CH}_{3}\right) \mathrm{CO}_{2}\left(\mathrm{CH}_{2}\right)_{3} \mathrm{Si}\left(\mathrm{OCH}_{3}\right)_{3}\right)$; TIP (titanium (IV) isopropoxideTi $\left.\left(\mathrm{OC}_{3} \mathrm{H}_{7}\right)_{4}\right)$; and nitrates $\mathrm{AgNO}_{3}, \mathrm{Cu}\left(\mathrm{NO}_{3}\right)_{2} \times 3 \mathrm{H}_{2} \mathrm{O}$, and $\mathrm{Zn}\left(\mathrm{NO}_{3}\right)_{2} \times 6 \mathrm{H}_{2} \mathrm{O}$ (Sigma Aldrich, Krakow, Poland) as a source of metallic ions.

First, the metallic precursor was dissolved in propanol, serving as a solvent. The solution was mixed for $30 \mathrm{~min}$ in a magnetic stirrer. Next, TEOS, TMSPM, and TIP were successively added to the solution. Having introduced each of the reagents, we then stirred 
the solution for $20 \mathrm{~min}$. The aqueous solution of the $\mathrm{HNO}_{3}$ nitric acid was used as a reaction catalyst. The volume ratio of all the components to the propanol solvent was 1:8. Prior to layering, the solution aging time was $24 \mathrm{~h}$, and the viscosity equaled $6 \mathrm{cP}$. The obtained sol was stored in a sealed container, with no access to UV and VIS radiation in order to limit the $\mathrm{Ag}^{+}$reduction. The discs were washed with propanol. The layers were applied by the dip coating technique with the $50 \mathrm{~mm} / \mathrm{min}$ withdrawal speed, and then the coated discs were drying in ambient conditions for $24 \mathrm{~h}$. Next, the applied layers were stabilized by the two-step thermal treatment at $80^{\circ} \mathrm{C}$ for $10 \mathrm{~min}$ and $130{ }^{\circ} \mathrm{C}$ for $15 \mathrm{~min}$.

The following nomenclature was adopted to standardize the names of the samples in this work (Table 1).

Table 1. Samples nomenclature.

\begin{tabular}{cc}
\hline Sample Characteristic & Sample Nomenclature \\
Titanium alloy Ti-6Al-4V & $\mathrm{TiAlV}$ \\
Titanium alloy Ti-6Al-4V with pure hybrid layer & $\mathrm{TiAlV} / \mathrm{h} 2 \mathrm{Ag}$ \\
Titanium alloy Ti-6Al-4V with hybrid layer containing $2 \mathrm{~mol} \% \mathrm{AgNPs}$ & $\mathrm{TiAlV} / \mathrm{h} 5 \mathrm{Ag}$ \\
Titanium alloy Ti-6Al-4V with hybrid layer containing $5 \mathrm{~mol} \% \mathrm{AgNPs}$ & $\mathrm{TiAlV} / \mathrm{h} 2 \mathrm{Cu}$ \\
Titanium alloy Ti-6Al-4V with hybrid layer containing 2 mol \% CuNPs & $\mathrm{TiAlV} / \mathrm{h} 5 \mathrm{Cu}$ \\
Titanium alloy Ti-6Al-4V with hybrid layer containing $5 \mathrm{~mol} \mathrm{\%} \mathrm{CuNPs}$ & $\mathrm{TiAlV} / \mathrm{h} 2 \mathrm{Zn}$ \\
Titanium alloy Ti-6Al-4V with hybrid layer containing 2 mol \% ZnNPs & $\mathrm{TiAlV} / \mathrm{h} 5 \mathrm{Zn}$ \\
Titanium alloy Ti-6Al-4V with hybrid layer containing $5 \mathrm{~mol} \% \mathrm{ZnNPs}$ & \\
\hline
\end{tabular}

\subsection{Material Examinations}

\subsubsection{Scanning Electron Microscopy}

The detailed microstructure examination of the materials was carried out by means of the Nova NanoSEM 200 scanning electron microscope (FEI, Eindhoven, The Netherlands) with the Genesis XM X-ray microanalysis system (EDAX, Tilburg, The Netherlands) featuring the EDAX Sapphire $\mathrm{Si}(\mathrm{Li})$ EDS detector. The observations and measurements took place in low vacuum conditions using a Helix detector (SE) with the accelerated voltage of $10-18 \mathrm{kV}$.

\subsubsection{XRD X-ray Diffractometry}

The XRD patterns of the samples were obtained using Malvern PANalytical Empyrean diffractometer (Worcestershire, UK) equipped with a copper lamp (monochromatic radiation with $0.1530598 \mathrm{~nm} \mathrm{CuK} \alpha 1$ and $0.1544938 \mathrm{~nm} \mathrm{CuK} \alpha 2$ lines) and a PiXcel3D detector. All the samples were measured in Programmable Divergence Slit (PDS) mode in two ways: (1) silver, copper, and zinc nanoparticles in the $\mathrm{SiO}_{2}$ matrix were spread on the metallic (TiAlV) alloy; (2) silver, copper, and zinc nanoparticles in the $\mathrm{SiO}_{2}$ matrix were spread on the glass plate.

The data analysis was carried out using X'pert High Score software with PDF + 2021 database, and it was supported by the Rietveld analysis using GSAS + EXPGUI software [45,46].

\subsubsection{Fourier Transform Infrared Spectroscopy, FTIR}

The structural changes caused by the chemical modification of the substrates with the sol-gel layers were investigated using the BTS-RAD FTS 3000 Excalibur spectrophotometer (Bio-Rad, Hertfordshire, UK). The ATR technique (MIRACLE attachment equipped with ZnSe doped diamond crystal) was used. The tests were carried out in the range of $400-4000 \mathrm{~cm}^{-1}$ with a resolution of $4 \mathrm{~cm}^{-1}$.

\subsubsection{Surface Wettability}

The static water contact angle (WCA) was used to assess the surface wettability via the sessile drop method with the automatic drop shape analysis system DSA 10 Mk2 (Kruss $\mathrm{GmbH}$, Hamburg, Germany). The constant temperature and humidity conditions were maintained throughout the tests, while the UHQ-water droplets of $0.25 \mu \mathrm{L}$ were applied 
on each pure and dry sample. We calculated the apparent contact angle as an average of 30 measurements and expressed it as the mean \pm standard deviation (SD).

\subsubsection{Surface Free Energy}

The free surface energy was determined by testing the contact angles of two measuring liquids: ultra-pure distilled water (UHQ PURE Lab., Vivendi Water, Paris, France) and diiodomethane. The measurements were carried out on the DSA 10 Mk2 optical apparatus (Kruss GmbH, Hamburg, Germany) at room temperature. The test pattern was identical to the contact angle test. The obtained photos of drops of two measuring liquids established the free surface energy on the basis of the values of the dispersion and polar components. The value was the arithmetic average obtained from 30 measurements. The results are presented with standard deviations (SD).

\subsubsection{Roughness}

The arithmetical mean roughness $(R a)$ and the root mean square roughness $(R q)$ of the investigated materials were evaluated by means of the contact profilometer HOMMELETAMIC T1000 wave (Jenoptik AG, Jena, Germany). The arithmetical mean roughness values were an average of 10 measurements with traverse length $4.8 \mathrm{~mm}$ according to the EN ISO 4288 expressed as the mean \pm standard deviation (SD).

\subsubsection{Confocal Microscopy}

The surface topography of samples was observed using the laser confocal microscope Lext OLS 4000 (Olympus, Tokyo, Japan) with the magnification $50 \times$. The scanned area was $640 \times 640 \mu \mathrm{m}$.

\subsubsection{Statistical Analysis}

The results were analyzed using one-way analysis of variance (ANOVA) with Duncan's posthoc tests, which were performed with Statistica 13.1 software (TIBCO Software Inc., Palo Alto, CA, USA). The results were considered statistically significant when $p<0.05$.

\section{Conclusions}

The conducted microscopic studies proved that it was possible to obtain hybrid layers with the different microstructures of the layers themselves and various nanoparticle morphologies. The layers obtained by the sol-gel technique differed depending on the precursor used. The conducted research confirmed that silver, copper, and zinc nanoparticles differed in shape and size. The studies showed that silver nanoparticles were the most evenly distributed in the organosilicon matrix, while copper and zinc nanoparticles formed agglomerates, and zinc caused layer porosity. The FTIR and XRD structural studies confirmed the silicon matrix and metal nanoparticle presence, respectively. The TiAlV alloy layer modification changed the surface properties, such as wettability, surface energy, and roughness. The layers containing silver nanoparticles increased the value of the contact angle, thus lowering the surface energy. The layers containing copper and zinc nanoparticles showed different behavior. The modification of the titanium alloy with hybrid layers certainly affected the roughness parameter, causing its significant decrease. Thus, the performed tests proved that it was possible to smooth the alloy surface and protect it against surgical scratches and scrapes during the same process.

Author Contributions: M.Z. was responsible for conceptualization, validation, formal analysis, SEM analysis, data curation, writing — original draft preparation, and writing — review and editing. K.C.-K. was responsible for conceptualization, validation, hybrid layer preparation, and writing-original draft preparation. K.M. was responsible for performing surface and structural measurements. K.W. was responsible for performing XRD analysis and writing-original draft preparation. M.G. was responsible for performing confocal microscopy observation. All authors have read and agreed to the published version of the manuscript. 
Funding: This work was carried out within INKUBATOR INNOWACYJNOŚCI 4.0, MNiSW /2020/ 316/DIR, financed by the Ministry of Education and Science.

Institutional Review Board Statement: Not applicable.

Informed Consent Statement: Not applicable.

Data Availability Statement: Not applicable.

Conflicts of Interest: The authors declare no conflict of interest.

\section{References}

1. Li, X.; Wang, C.-T.; Zhang, W.-G.; Li, Y.-C. Properties of a porous Ti-6Al-4V implant with a low stiffness for biomedical application. Proc. Inst. Mech. Eng. Part H J. Eng. Med. 2009, 223, 173-178. [CrossRef] [PubMed]

2. Zhang, Y.; Sun, D.; Cheng, J.; Tsoi, J.K.H.; Chen, J. Mechanical and biological properties of Ti-(0-25 wt \%)Nb alloys for biomedical implants application. Regen. Biomater. 2020, 7, 119-127. [CrossRef] [PubMed]

3. Niu, J.; Guo, Y.; Li, K.; Liu, W.; Dan, Z.; Sun, Z.; Zhou, L. Improved mechanical, bio-corrosion properties and in vitro cell responses of Ti-Fe alloys as candidate dental implants. Mater. Sci. Eng. C 2021, 122, 111917. [CrossRef] [PubMed]

4. Hsu, H.-C.; Wu, S.-C.; Hsu, S.-K.; Sung, Y.-C.; Ho, W.-F. Effects of heat treatments on the structure and mechanical properties of Zr-30Ti alloys. Mater. Charact. 2011, 62, 157-163. [CrossRef]

5. Quinn, J.; McFadden, R.; Chan, C.-W.; Carson, L. Review: Titanium for Orthopedic Applications: An Overview of Surface Modification to Improve Biocompatibility and Prevent Bacterial Biofilm Formation. iScience 2020, 23, 101745. [CrossRef]

6. Carr, B.C.; Goswami, T. Knee implants-Review of models and biomechanics. Mater. Des. 2009, 30, 398-413. [CrossRef]

7. Kim, T.; See, C.W.; Li, X.; Zhu, D. Orthopedic implants and devices for bone fractures and defects: Past, present and perspective. Eng. Regen. 2020, 1, 6-18. [CrossRef]

8. Warburton, A.; Girdler, S.J.; Mikhail, C.M.; Ahn, A.; Cho, S.K. Biomaterials in Spinal Implants: A Review. Neurospine 2020, 17, 101-110. [CrossRef]

9. AlvachianFernandes, H.J.; Saad, E.A.; Reis, F.B. Osteosynthesis with intramedullary nails in children. Rev. Ortop. (Engl. Ed.) 2009, 44, 380-385. [CrossRef]

10. Pieske, O.; Geleng, P.; Zaspel, J.; Piltz, S. Titanium Alloy Pins Versus Stainless Steel Pins in External Fixation at the Wrist: A Randomized Prospective Study. J. Trauma Inj. Infect. Crit. Care 2008, 64, 1275-1280. [CrossRef]

11. Ho, W.-F.; Chen, W.-K.; Wu, S.-C.; Hsu, H.-C. Structure, mechanical properties, and grindability of dental Ti-Zr alloys. J. Mater. Sci. Mater. Med. 2008, 19, 3179-3186. [CrossRef]

12. Ahmed, S.; Shellock, F.G. Magnetic Resonance Imaging Safety: Implications for Cardiovascular Patients. J. Cardiovasc. Magn. Reson. 2001, 3, 171-182. [CrossRef]

13. Morinaga, M. Titanium Alloys. In A Quantum Approach to Alloy Design; Elsevier Science Publishing Co., Inc.: Amsterdam, The Netherlands, 2019; pp. 77-94. [CrossRef]

14. Costa, B.C.; Tokuhara, C.K.; Rocha, L.A.; Oliveira, R.C.; Lisboa-Filho, P.N.; Pessoa, J.C. Vanadium ionic species from degradation of Ti-6Al-4V metallic implants: In vitro cytotoxicity and speciation evaluation. Mater. Sci. Eng. C 2019, 96, 730-739. [CrossRef]

15. Korbecki, J.; Baranowska-Bosiacka, I.; Gutowska, I.; Chlubek, D. Vanadium Compounds as Pro-Inflammatory Agents: Effects on Cyclooxygenases. Int. J. Mol. Sci. 2015, 16, 12648-12668. [CrossRef]

16. Liu, X.; Chu, P.K.; Ding, C. Surface modification of titanium, titanium alloys, and related materials for biomedical applications. Mater. Sci. Eng. R Rep. 2004, 47, 49-121. [CrossRef]

17. Fuentes, E.; Alves, S.; López-Ortega, A.; Mendizabal, L.; de Viteri, V.S. Advanced Surface Treatments on Titanium and Titanium Alloys Focused on Electrochemical and Physical Technologies for Biomedical Applications; IntechOpen: London, UK, 2019. [CrossRef]

18. Danışman, Ş.; Odabas, D.; Teber, M. The Effect of Coatings on the Wear Behavior of Ti6Al4V Alloy Used in Biomedical Applications. IOP Conf. Ser. Mater. Sci. Eng. 2018, 295, 012044. [CrossRef]

19. Brinker, C.; Scherer, G. Sol-Gel Science: The Physics and Chemistry of Sol-Gel Processing; Academic Press: San Diego, CA, USA, 1989.

20. Hsieh, M.-F.; Perng, L.-H.; Chin, T.-S. Hydroxyapatite coating on Ti6Al4V alloy usinga sol-gel derived precursor. Mater. Chem. Phys. 2002, 74, 245-250. [CrossRef]

21. Asri, R.I.; Harun, W.S.; Hassan, M.A.; Ghani, S.A.; Buyong, Z. A review of hydroxyapatite-based coating techniques: Sol-gel and electrochemical depositions on biocompatible metals. J. Mech. Behav. Biomed. Mater. 2016, 57, 95-108. [CrossRef]

22. Milošev, I.; Hamulić, D.; Rodič, P.; Carrière, C.; Zanna, S.; Budasheva, H.; Korte, D.; Franko, M.; Mercier, D.; Seyeux, A.; et al Siloxane polyacrylic sol-gel coatings with alkly and perfluoroalkyl chains: Synthesis, composition, thermal properties and log-term corrosion protection. Appl. Surf. Sci. 2022, 574, 151578. [CrossRef]

23. Romero-Gavilán, F.; Carlos-Almeida, J.; Cerqueira, A.; Gurruchaga, M.; Goñi, I.; Miranda-Salvado, I.M.; VazFernandes, M.H.; Suay, J. Sol-gel coatings made using methyl-modified alkoxysilanes: The balance between protection and bioactivation. Prog. Org. Coat. 2020, 147, 105770. [CrossRef]

24. Ferraris, S.; Spriano, S. Antibacterial titanium surfaces for medical implants. Mater. Sci. Eng. C 2016, 61, 965-978. [CrossRef] 
25. Cerqueira, A.; Romero-Gavilán, F.; García-Arnáez, I.; Martinez-Ramos, C.; Ozturan, S.; Iloro, I.; Azkargorta, M.; Elortza, F.; Izquierdo, R.; Gurruchaga, M.; et al. Bioactive zinc-doped sol-gel coating modulates protein adsorption patterns and in vitro cell responses. Mater. Sci. Eng. C Mater. Biol. Appl. 2021, 121, 111839. [CrossRef]

26. Jeon, H.J.; Yi, S.C.; Oh, S.G. Preparation and antibacterial effects of $\mathrm{Ag}-\mathrm{SiO}_{2}$ thin films by sol-gel method. Biomaterials 2003, 24, 4921-4928. [CrossRef]

27. Lee, S.M.; Lee, B.S.; Byun, T.G.; Song, K.C. Preparation and antibacterial activity of silver-doped organic-inorganic hybrid coatings on glass substrates. Colloids Surf. A Physicochem. Eng. Asp. 2010, 355, 167-171. [CrossRef]

28. Marini, M.; De Niederhausern, S.; Iseppi, R.; Bondi, M.; Sabia, C.; Toselli, M.; Pilati, F. Antibacterial Activity of Plastics Coated with Silver-Doped Organic-Inorganic Hybrid Coatings Prepared by Sol-Gel Processes. Biomacromolecules 2007, 8 , 1246-1254. [CrossRef]

29. Šlamborová, I.; Zajícová, V.; Karpíšková, J.; Exnar, P.; Stibor, I. New type of protective hybrid and nanocomposite hybrid coatings containing silver and copper with an excellent antibacterial effect especially against MRSA. Mater. Sci. Eng. C 2013, 33, 265-273. [CrossRef]

30. Procaccini, R.A.; Studdert, C.A.; Pellice, S.A. Silver doped silica-methyl hybrid coatings. Structural evolution and antibacterial properties. Surf. Coat. Technol. 2014, 244, 92-97. [CrossRef]

31. Cui, F.; Yu, Y.; Dou, L.; Sun, J.; Yang, Q.; Schildknecht, C.; Schierle-Arndt, K.; Yang, P. Synthesis of Ultrathin Copper Nanowires Using Tris(trimethylsilyl)silane for High-Performance and Low-Haze Transparent Conductors. Nano Lett. 2015, 15, 7610-7615. [CrossRef] [PubMed]

32. Da Silva Biron, D.; Santos, V.; Bergmann, C.P. Synthesis and Characterization of Zinc Oxide Obtained by Combining Zinc Nitrate with Sodium Hydroxide in Polyol Medium. Mater. Res. 2020, 23, e20200080. [CrossRef]

33. Hah, H.J.; Koo, S.M. Preparation of Silver Nanoparticles through Alcohol Reduction with Organoalkoxysilane. J. Sol-Gel Sci. Technol. 2003, 26, 467-471. [CrossRef]

34. Ziąbka, M.; Kiszka, J.; Trenczek-Zając, A.; Radecka, M.; Cholewa-Kowalska, K.; Bissenik, I.; Dziadek, A.K.M.; Niemiec, W.; Królicka, A Antibacterial composite hybrid coatings of veterinary medical implants. Mater. Sci. Eng. C 2020, 112, 110968. [CrossRef]

35. Deshmukh, P.; Bhatt, J.; Peshwe, D.; Pathak, S. Determination of Silica Activity Index and XRD, SEM and EDS Studies of Amorphous SiO2 Extracted from Rice Husk Ash. Trans. Indian Inst. Met. 2011, 65, 63-70. [CrossRef]

36. Cho, A.-R.; Park, S.-Y. Synthesis of titania- and silica-polymer hybrid materials and their application as refractive index-matched layers in touch screens. Opt. Mater. Express 2015, 5, 690-703. [CrossRef]

37. Bressy, C.; Ngo, V.G.; Ziarelli, F.; Margaillan, A. New insights into the adsorption of 3-(trimethoxysilyl)propylmethacrylate on hydroxylated ZnO nanopowders. Langmuir 2012, 28, 3290-3297. [CrossRef]

38. Nguyen, T.-C.; Nguyen, T.-D.; Vu, D.-T.; Dinh, D.-P.; Nguyen, A.-H.; Ly, T.-N.-L.; Dao, P.-H.; Nguyen, T.-L.; Bach, L.-G.; Thai, H Modification of Titanium Dioxide Nanoparticles with 3-(Trimethoxysilyl)propyl Methacrylate Silane Coupling Agent. J. Chem. 2020, 2020, 1381407. [CrossRef]

39. Aflori, M.; Simionescu, B.; Bordianu, I.-E.; Sacarescu, L.; Varganici, C.-D.; Doroftei, F.; Nicolescu, A.; Olaru, M. Silsesquioxanebased hybrid nanocomposites with methacrylate units containing titania and/or silver nanoparticles as antibacterial/antifungal coatings for monumental stones. Mater. Sci. Eng. B Solid-State Mater. Adv. Technol. 2013, 178, 1339-1346. [CrossRef]

40. Siddiquey, I.A.; Ukaji, E.; Furusawa, T.; Sato, M.; Suzuki, N. The effects of organic surface treatment by methacryloxypropyltrimethoxysilane on the photostability of $\mathrm{TiO}_{2}$. Mater. Chem. Phys. 2007, 105, 162-168. [CrossRef]

41. Rodič, P.; Milošev, I.; Lekka, M.; Andreatta, F.; Fedrizzi, L. Corrosion behaviour and chemical stability of transparent hybrid sol-gel coatings deposited on aluminium in acidic and alkaline solutions. Prog. Org. Coat. 2018, 124, 286-295. [CrossRef]

42. Lakshmi, R.V.; Bera, P.; Anandan, C.; Basu, B.J. Effect of the size of silica nanoparticles on wettability and surface chemistry of sol-gel superhydrophobic and oleophobic nanocomposite coatings. Appl. Surf. Sci. 2014, 320, 780-786. [CrossRef]

43. Mahadik, S.A.; Mahadik, S.S. Surface morphological and topographical analysis of multifunctional superhydrophobic sol-gel coatings. Ceram. Int. 2021, 47, 29475-29482. [CrossRef]

44. MacHugh, E.; Cullen, M.; Kaworek, A.; Duffy, B.; Oubaha, M. The effect of curing and zirconium content on the wettability and structure of a silicate hybrid sol-gel material. J. Non-Cryst. Solids 2019, 525, 119658. [CrossRef]

45. Toby, B.H. EXPGUI, a graphical user interface for GSAS. J. Appl. Crystallogr. 2001, 34, 210-213. [CrossRef]

46. Rietveld, H.M. A profile refinement method for nuclear and magnetic structures. J. Appl. Crystallogr. 1969, 2, 65-71. [CrossRef] 